\title{
Canarypox Virus
}

National Cancer Institute

\section{Source}

National Cancer Institute. Canarypox Virus. NCI Thesaurus. Code C14315.

A poxvirus of the genus Avipoxvirus. Has been adapted as a cloning vector (canarypox vector) for use as a mammalian expression vector. 